\title{
TRANSPORT OF OXYGEN, NUTRIENTS AND CARBONATES BY THE KUROSHIO CURRENT
}

\author{
C. T. A. Chen \\ (Institute of Marine Geoloxn, National Sun Yat Sen University, Kawhsitny, Taiwann) \\ C. T. Liu and S. C. Pai \\ (Institute of Oceanography, National Taiwion University. Taipei, Taiwan)
}

Received Sep. 1, 1993

\begin{abstract}
Measured concentrations of dissolved oxygen, phosphate, silicate, total alkalinity and calculated total $\mathrm{CO}_{2}$ in a section between $121^{\circ} \mathrm{E}$ and $125^{\circ} \mathrm{E}$ across the Kuroshio near $22^{\circ} \mathrm{N}$ off Taiwan and the geostrophic velocity were used to estimate the gross transport of oxygen, nutrients and carbonates.

The flux of dissolved oxygen is $6.7 \times 10^{6} \mathrm{~mol} / \mathrm{s}$ northward and $0.9 \times 10^{6} \mathrm{~mol} / \mathrm{s}$ southward. The net flux equals $5.8 \times 10^{6} \mathrm{~mol} / \mathrm{s}$ downstream. The northward flux of phosphate is $22.6 \times 10^{3} \mathrm{~mol} / \mathrm{s}$; the southward flux is $1.4 \times 10^{3} \mathrm{~mol} / \mathrm{s}$. The net phosphate flux is $21.2 \times 10^{3} \mathrm{~mol} / \mathrm{s}$ northward. The flux of silicate is $967 \times 10^{3}$ northward and $59 \times 10^{3} \mathrm{~mol} / \mathrm{s}$ southward; the net transport is $908 \times 10^{3} \mathrm{~mol} / \mathrm{s}$ downstream. The flux of alkalinity is $75.5 \times 10^{6} \mathrm{~mol} / \mathrm{s}$ northwand, and $10.8 \times 10^{6} \mathrm{~mol} / \mathrm{s}$ southward, the net flux is $64.7 \times 10^{6} \mathrm{~mol} / \mathrm{s}$ northward. For total $\mathrm{CO}_{2}$ the transport is $73.4 \times 10^{6} \mathrm{~mol} / \mathrm{s}$ northward and $10.8 \times 10^{6} \mathrm{~mol} / \mathrm{s}$ southward, or a net transport of $62.6 \times 10^{6} \mathrm{~mol} / \mathrm{s}$ horthward.
\end{abstract}

Key words : transport, oxygen, nutrient, carbonates, Kuroshio Current

\section{INTRODUCTION}

The Kuroshio, like the Gulf Stream of the North Atlantic Ocean, is the strongest western boundary current of the North Pacific Ocean. It is generally considered to be originated from the area southeast of Taiwan and east of the Bashi Strait. The Kuroshio is characterized by its high speed, narrow width and great depth. It brings a large quantity of warm equatorial seawater while traveling northward along the east coast of Taiwan (Pai et al., 1987). Because of its characteristic high temperature and salinity, it has important impacts both on the local climate and the marine biological resources. Our interest is to quantitatively estimate the material fluxes carried by the Kuroshio.

The first quantitative estimates of nutrient fluxes are apparently those of Wunsch et al. (1983) for the Pacific. In the Atlantic, the first calculation of nutrient fluxes seems to be that of Brewer and Dyrssen (1987). They multiplied the average values by the net meridional transport in each depth class to find the net flux across $24^{\circ} \mathrm{N}$. Brewer et al. (1989), Csanady (1990) and Rintoul and Wunsch (1991) further extended the flux calculation in the North Atlantic Ocean to include nutrients, oxygen and $\mathrm{CO}_{2}$. We are not aware of similar work in the North Pacific.

The first cruise of the Cooperative Hydrographic Investigation of the Philippine Sea (CHIPS - 1) was carried out southeast of Taiwan, (Liu et al., 1986, 1987; Pai et al., 1987). In this note, we shall make use of these data to estimate both the flux-density 
(velocity times concentration), and the gross transport of dissolved oxygen, phosphate. silicate, alkalinity and total $\mathrm{CO}_{2}$.

\section{SOURCE OF DATA}

The hydrographic data used in this note were cited from the data report of CHIPS - 1 (Liu et al., 1987). Of the 27 CTD stations in Fig. 1 only 21 stations were chosen for chemical analysis. The analytical procodures in determining the dissolved oxygen, phosphate, silicate and total alkalinity were described in Pai et al. (1987).

The highest dissolved oxygen concentration $(4.4 \mathrm{ml} / \mathrm{L}$ to $4.9 \mathrm{ml} / \mathrm{L}$, near

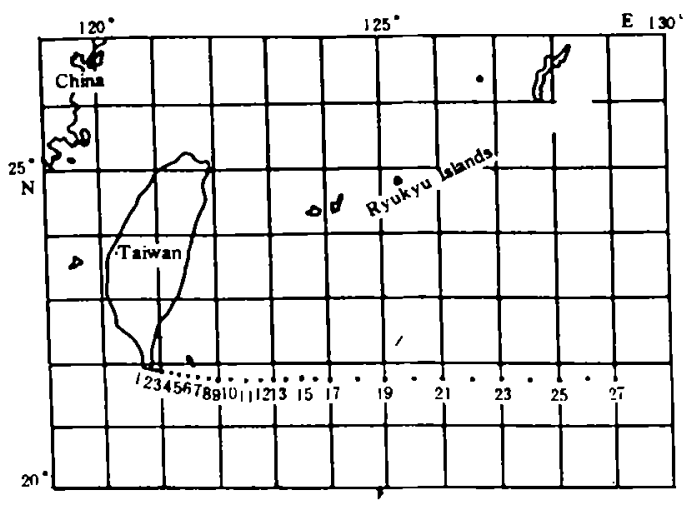

Fig. I Station location saturation) was found in the surface layer. The minimum was $1.6 \mathrm{ml} / \mathrm{L}$ at $1000 \mathrm{~m}$. The phosphate concentration increased with depth, ranging from $0.3 \mu \mathrm{mol} / \mathrm{L}$ near the surface to a maximum of about $3.0 \mu \mathrm{mol} / \mathrm{L}$. The distribution of silicate concentration was similar to that of phosphate, low in the surface layer and high in deep water, up to about $150 \mu \mathrm{mol} / \mathrm{L}$. The total alkalinity of surface seawater ranged from 2.3 to $2.4 \mathrm{mmol} / \mathrm{L}$ and increased with depth to a maximum of 2.5 $\mathrm{mmol} / \mathrm{L}$ between 2000-3000 m (Pai et al., 1987). The distribution of total $\mathrm{CO}_{2}$ (calculated from $\mathrm{pH}$ and alkalinity; Chen, 1984) was similar to that of alkalinity, with conœentrations ranging from 2.0 to 2.6 $\mathrm{mmol} / \mathrm{L}$. The geostrophic velocity (Fig.2) was based on the $1000 \mathrm{~dB}$ surface as the reference level. (Liu et al., 1986)

Fiften stations (St. 2-19) between $121^{\circ} \mathrm{E}$ and $125^{\circ} \mathrm{E}$ were chosen for flux extimations. Currents further east were too low for accurate flux estimations.

\section{RESULTS AND DISCUSSION}

The calculated geostrophic velocity was based on a level of no motion at $1000 \mathrm{~dB}$. (Fig.2) The results agree with that obtained by Nitani (1972). There were two northward current bands and a weak southward current (from $124^{\circ} \mathrm{E}$ to $125^{\circ} \mathrm{E}$ ). The flux densities of oxygen, nutrients and carbonates were calculated by multiplying velocity by concentration. Integrating these data gives the total fluxes shown in Table 1.

\section{Oxygen:}

Fig. 3 shows the flux-density of dissolved oxygen ranging from -104 to 260 $\mathrm{mmol} / \mathrm{m}^{2} \mathrm{~s}$ (positive sign indicates northward flow), with a maximum at St. 5. Since the flux-density is dominated by concentraion and velocity, and both decrease with depth, 
the flux-density structure of dissolved oxygen was similar to the velocity structure. The gross flux of oxygen at this $400 \mathrm{~km}$ wide section was $6.7 \times 10^{6} \mathrm{~mol} / \mathrm{s}$ northward and

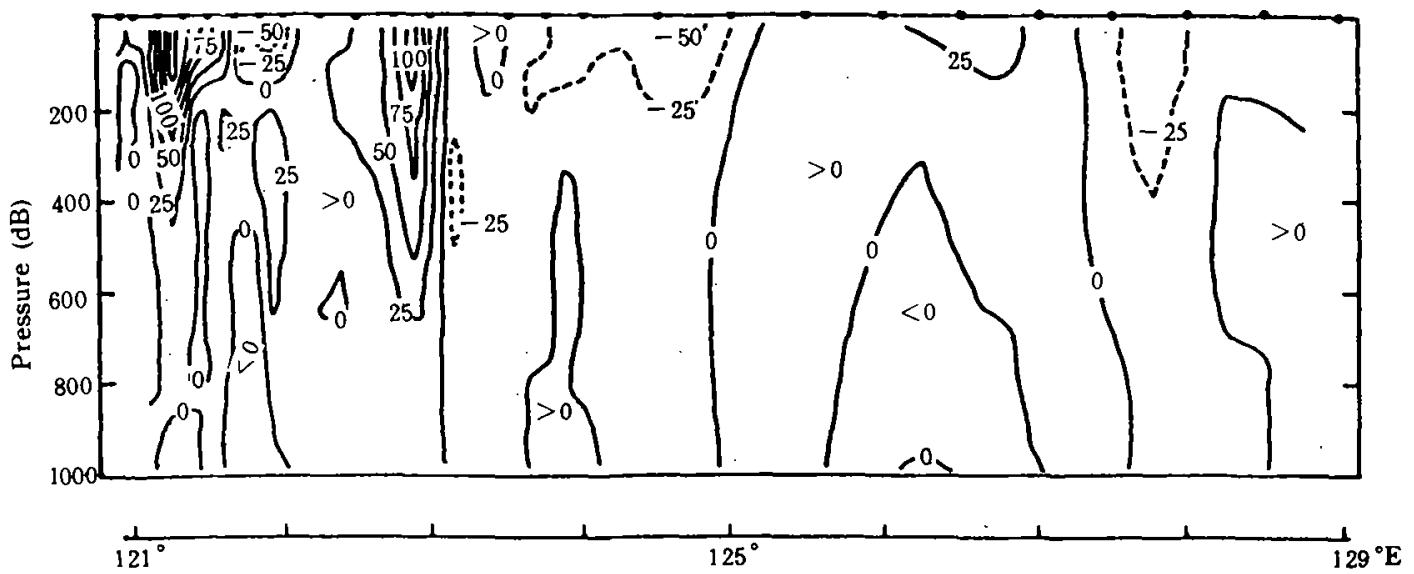

Fig. 2 Geostrophic velocity at the section near $22^{\circ} \mathrm{N}$, contours are in oentimeter per seoond and the positive sign indicates northward flow (Data from Liu et al., 1986)

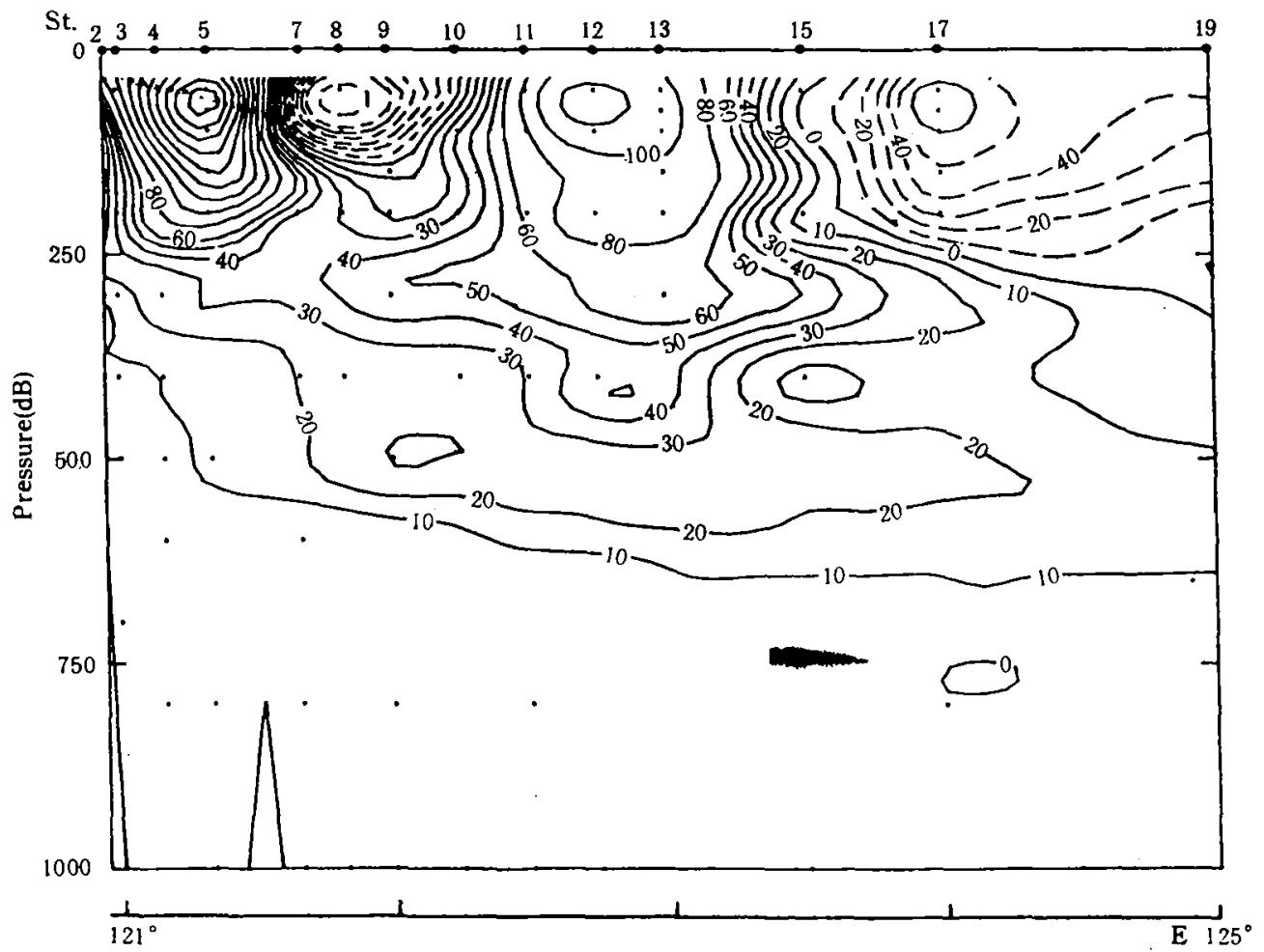

Fig. 3 Along-stream flux-density of dissolved oxygen $\left(\mathrm{mmol} / \mathrm{m}^{2} \mathrm{~s}\right)$ at a section near $22^{\circ} \mathrm{N}$ 
$0.9 \times 10^{6} \mathrm{~mol} / \mathrm{s}$ southward, yielding a net flux $5.8 \times 10^{6} \mathrm{~mol} / \mathrm{s}$ down-stream, or contributing $183 \times 10^{12}$ moles for this section per year.

\section{Phosphate:}

The distribution of flux-density for phosphate is shown in Fig. 4. The values ranged from -125.4 to $450.3 \mu \mathrm{mol} / \mathrm{m}^{2} \mathrm{~s}$ with a maximum at $500 \mathrm{~m}$ at St. 9. There was a maximum core located at $500 \mathrm{~m}$, just below the high velocity core of the Kuroshio. The Gulf Stream shows a similar pattern (Csanady, 1990). The total flux of phosphate across this section was $22639 \mathrm{~mol} / \mathrm{s}$ northward and $1462 \mathrm{~mol} / \mathrm{s}$ southward, yielding a northward net flux of about $21177 \mathrm{~mol} / \mathrm{s}$. This amounts to a phosphate transport of $668 \times 10^{9}$ moles per year.

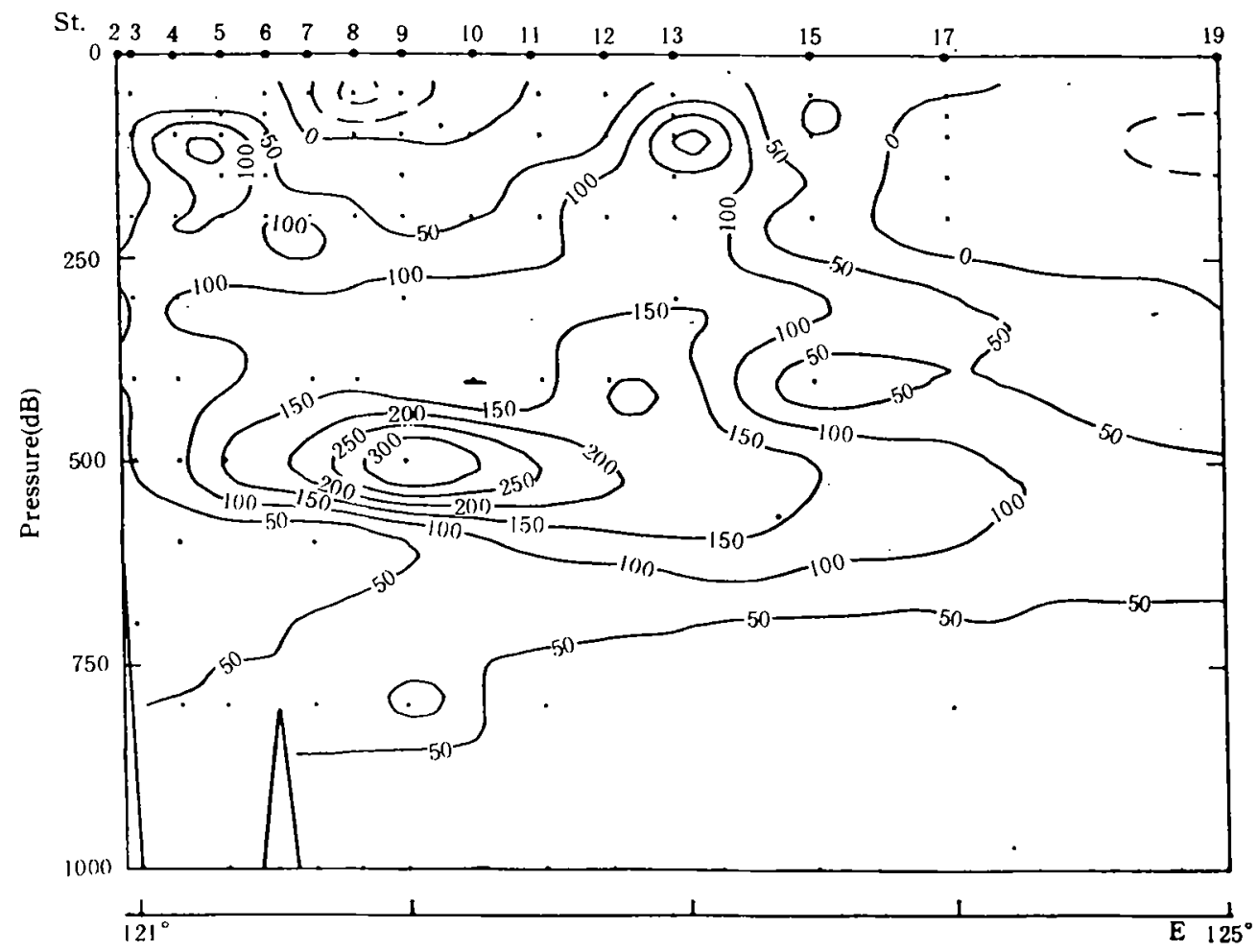

Fig. 4 Along-stream flux-density of phosphate $\left(\mathrm{mmol} / \mathrm{m}^{2} \mathrm{~s}\right)$ at a section near $22^{\circ} \mathrm{N}$

\section{Silicate:}

The flux-density of silicate ranging from -3.66 to $17.76 \mathrm{mmol} / \mathrm{m}^{2} \mathrm{~s}$ is shown in Fig.5 showing a silicate stream core at about $500 \mathrm{~m}$ below the high velocity core. The 
negative values, at St. 8-10 and St. 17-19, indicate the southward transport of currents. The silicate flux was $967 \times 10^{3} \mathrm{~mol} / \mathrm{s}$ northward and $59 \times 10^{3} \mathrm{~mol} / \mathrm{s}$ southward. The net northward flux of silicate was $908 \times 10^{3} \mathrm{~mol} / \mathrm{s}$ or $28.6 \times 10^{12}$ moles per year, some forty times the net phosphate flux. For nutrients, the northward transport was about sixteen times the southward transport.

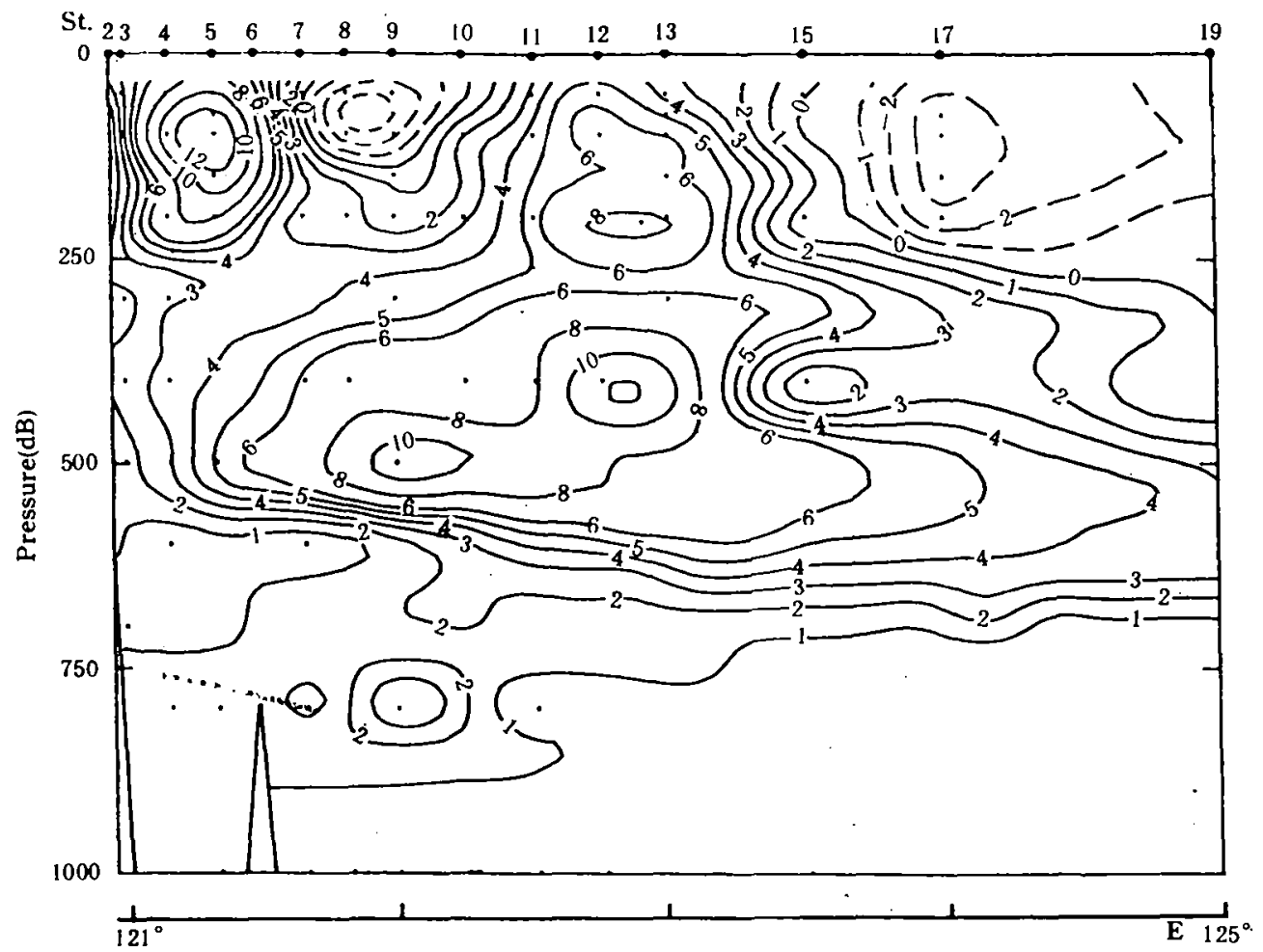

Fig. 5 Along-stream flux-density of silicate (mmol/m's) at a section. near $22^{\circ} \mathrm{N}$

\section{Alkalinity:}

The inferred alkalinity flux-density (Fig.6) had banarstructures similar to that of the geostrophic velocity (Fig. 2). The downstream maximum transport of alkalinity by the Kuroshio at this latitude was $3029 \mathrm{mmol} / \mathrm{m}^{2} \mathrm{~s}$ in the western part close to the coast. The southward maximum flow was $.1150 \mathrm{mmol} / \mathrm{m}^{2} \mathrm{~s}$ at $\mathrm{St}$. 8 at about $50 \mathrm{~m}$. The inferred alkalinity flux (Table 1) transported by the Kuroshio was $75.5 \times 10^{6} \mathrm{~mol} / \mathrm{s}$ northward. The southward transport was $10.8 \times 10^{6} \mathrm{~mol} / \mathrm{s}$; thus the net alkalinity flux was $64.7 \times 10^{6}$ $\mathrm{mol} / \mathrm{s}$ or $2.04 \times 10^{15} \mathrm{~mol} / \mathrm{a}$ northward. 
Table 1 Fstimates of northwand oxygen, phosphate, silicate, alkalinity and total $\mathrm{CO}_{2}$ fluxes at $22^{\circ} \mathrm{N}$ between $121^{\circ}$ and $125^{\circ} \mathrm{E}$

\begin{tabular}{lccccc}
\hline \multicolumn{7}{c}{ Flux } \\
\hline Depth & $\begin{array}{c}\text { Dissolved oxygen } \\
\left(10^{3} \mathrm{~mol} / \mathrm{s}\right)\end{array}$ & $\begin{array}{c}\text { Phosphate } \\
(\mathrm{mol} / \mathrm{s})\end{array}$ & $\begin{array}{c}\text { Silicate } \\
(\mathrm{mol} / \mathrm{s})\end{array}$ & $\begin{array}{c}\text { Alkalinity } \\
\left(10^{3} \mathrm{~mol} / \mathrm{s}\right)\end{array}$ & $\begin{array}{c}\text { Total } \mathrm{CO}_{2} \\
\left(10^{3} \mathrm{~mol} / \mathrm{s}\right)\end{array}$ \\
\hline $50-250 \mathrm{~m}$ & 2370 & 2666 & 149370 & 22031 & 19768 \\
$251-500 \mathrm{~m}$ & 2445 & 8480 & 425994 & 28577 & 30247 \\
$501-750 \mathrm{~m}$ & 940 & 7674 & 286026 & 10987 & 9658 \\
$751-1000 \mathrm{~m}$ & 43 & 2357 & 46668 & 3065 & 2918 \\
Total flux & 5,98 & 21177 & 908058 & 64660 & 62591 \\
\hline
\end{tabular}

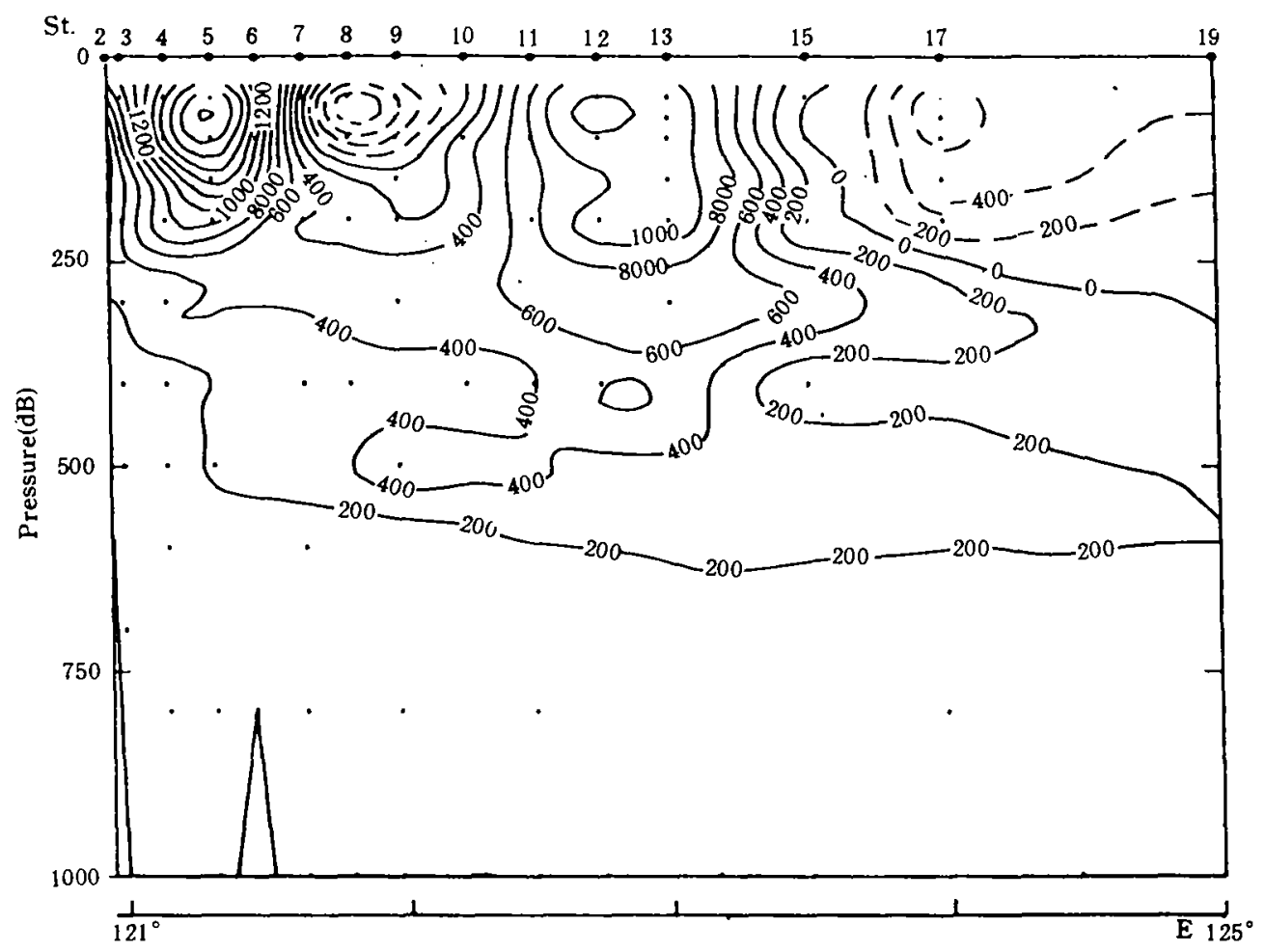

Fig. 6 Along-stream flux-density of total alkalinity $\left(\mathrm{mmol} / \mathrm{m}^{2} \mathrm{~s}\right)$ at a section near $22^{\circ} \mathrm{N}$

\section{Total $\mathrm{CO}_{2}$}

Total CQ flux-density (Fig. 7), similar to that of alkalinity, also showed the band structure. Northward flow maximum of about $2694 \mathrm{mmol} / \mathrm{m}$ 's located at St. 5 at $75 \mathrm{~m}$, and southward maximum of $1002 \mathrm{mmol} / \mathrm{m}^{2} \mathrm{~s}$ located at St. 8 at $50 \mathrm{~m}$. For total $\mathrm{CO}_{2}$ the transports were $73.4 \times 10^{6} \mathrm{~mol} / \mathrm{s}$ northward and $10.8 \times 10^{6} \mathrm{~mol} / \mathrm{s}$ southward. These val- 
ues yield a net northward flux of $62.6 \times 10^{6} \mathrm{~mol} / \mathrm{s}$, or $23.7 \times 10^{9}$ tons $\mathrm{C}$ per year. For both alkalinity and total $\mathrm{CO}_{2}$, the northward flow transported some seven times the southward flow.

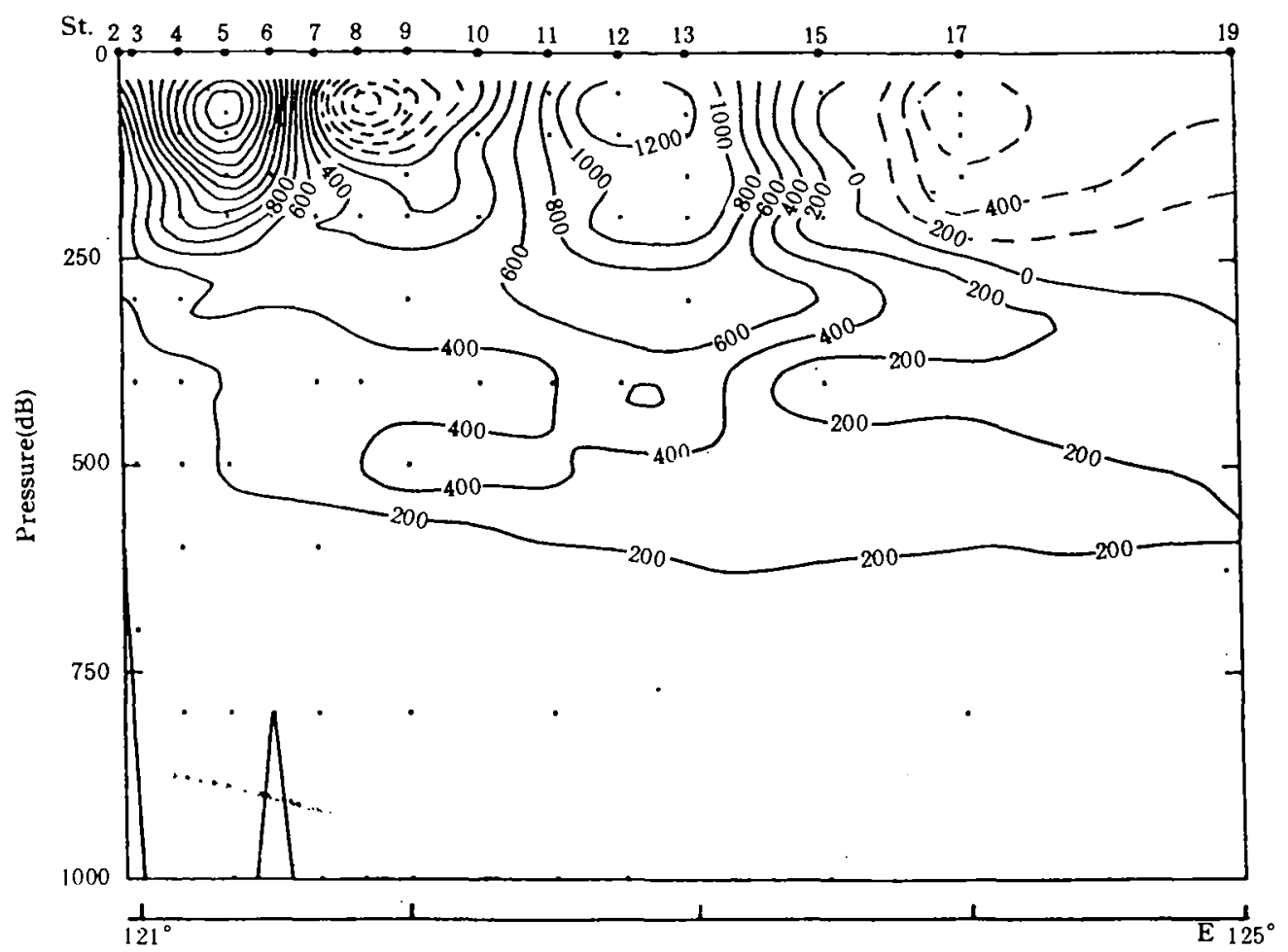

Fig. 7 Along-stream flux-density of total $\mathrm{CO}_{2}\left(\mathrm{mmol} / \mathrm{m}^{2} \mathrm{~s}\right)$ at a section near $22^{\circ} \mathrm{N}$

\section{CONCLUSION}

1. The flux-densities of phosphate and silicate by the Kuroshio at $22^{\circ} \mathrm{N}$ showed along-stream cores between 400 and $500 \mathrm{~m}$, below the high-velocity core (between the surface and $200 \mathrm{~m}$ ) of Kuroshio current.

2. The flux-density distributions of alkalinity and toutar $\mathrm{CO}_{2}$ were similar to that of the velocity structure, indicating that both of them were dominated by the velocity field.

3. The gross northward fluxes of dissolved oxygen, phosphate, silicate, alkalinity and total $\mathrm{CO}_{2}$ were $5.8 \times 10^{6} \mathrm{~mol} / \mathrm{s}, 21.2 \times 10^{3} \mathrm{~mol} / \mathrm{s}, 908 \times 10^{3} \mathrm{~mol} / \mathrm{s}, 64.7 \times 10^{6} \mathrm{~mol} / \mathrm{s}$ and $62.6 \times 10^{6}$ $\mathrm{mol} / \mathrm{s}$, respectively.

\section{ACKNOWLEDGEMENTS}

The National Science Council supported the research (NSC 82-0209-M-110-041). C. H. Wang provided assistance. 


\section{References}

Brewer. P. G. and Dyrssen, D., 1987. Oocan chemical fluxes across $25^{\circ} \mathrm{N}$ in the Atlantic Ocean. Discussion paper preparod for the International GOFS meeting. Paris, 17-20, Fcb. 1987. $25 \mathrm{pp}$.

Brewer, P. G. Goyet, C. and Dyrssen. D., 1989. Carbon dioxide transport by ocean currents at $25^{\circ} \mathrm{N}$ latitude in the Atlantic Ocean. Science 246: 477-479.

Chen, C. T., 1984. Carbonate chemistry of the Weddell Sea. Department of Energy Technical Report. DOE/EV/10611-4, $118 \mathrm{pp}$.

Csanady, G. T., 1990. Physical basis of coastal productivity. EOS. 71(36): 1060-1065.

Liu, C. T., Liau, S. G., Pai, S. C. et al., 1986. Water masses in the Western Philippine Sea-physical aspects. Acta Oceanoyraphica Taiwanica 17: 1-17.

Liu, C. T., Pai, S. C., Liau, S. G. et al., 1987, Data report of CHIPS - 1, Institute of Oceanography. National Taiwan University, $118 \mathrm{pp}$.

Nitani, H.. 1972. Beginning of the Kuroshio. In Kuroshio. University of Tokyo Press, Japan, pp. $129-163$.

Pai, S. C., Liu, C. J., Wen, L. S. et al., 1987. Primary investigation of the Westem Philippine Sea water-chemical data from the CHIPS - I expedition. Yearly Joumal of the National Taiwan College of Marine Science and Technology 21: $49-68$.

Rintoul, S. R. and Wunsch, C., 1991. Mass, heat, oxygen and nutrient fluxes and budgets in the North Atlantic Ocean. Deep-Sea Research 38 (Suppl. 1): S355-S377.

Wunsch, C., Hu D. and Grant, B., 1983, Mass, heat and nutrient fluxes in the South Pacific Ocean. Joumal of Physical Oceanography 13: 725-753. 